\title{
Thinking and Language in the Body / Psyche Issue: A Cognitive Ethology Focused on Human Being
}

\author{
Felicia Ceauşu, ${ }^{1, *}$, George Ceaușu ${ }^{2}$ \\ ${ }^{1}$ Romanian Academy, Iaşi Branch, Romania \\ ${ }^{2}$ Faculty of Philosophy, Alexandru Ioan Cuza University, Romania
}

Copyright $\mathrm{O} 2017$ by authors, all rights reserved. Authors agree that this article remains permanently open access under the terms of the Creative Commons Attribution License 4.0 International License

\begin{abstract}
This article aims to investigate the relationship between thinking and language. In the early years of life, natural language develops in close connection with intelligence, configuring broadly the features of thought. The child's mind has a limited number of reference systems from which it can, through experience, constitute the qualities that underlie the processing of knowledge and the skills formed at the representation level. In maturity, at the same time as the development of thinking, the mind constructs signification and communication procedures that go beyond natural language. The language of a community is a development environment for the individual due to the close relationship between thinking and speech. By summoning various cultural resources, we can conclude that the language contains our image of the world: in this regard, symbolic imagination is stronger than iconic (based on signs and symptoms of visual). We will address the body / psyche problem and not the body / soul from the point of view of the philosophy of mind. Consequently, we will use the scientific themes of body and psyche. Our body is clearly and distinctly perceived by the other bodies and its perception also indicates a direction of exploration of the world from the inside to the outside: my body, the bodies of the others, then the anorganic bodies in the outer space.
\end{abstract}

Keywords Thinking, Language, Psyche

\section{Issues ofNeurolinguistics: "Universal Grammar" and the Language-thinking Relation in Children and Adults}

In our approach, we will confer all our trust to a philosophy of the language but also to some classical fields of philosophy such as metaphysics, gnosiology and logics. Metaphysics creates a certain tension between physics and the human knowing subject around who a particular anthropology formed throughout the time. Together with its metaphysics, partially "spilled" later on in hermeneutics, the human being intervenes in the speech about existence with its own values (ethical, logical, esthetical, political), therefore, complicating it even more.

According to Ferdinand de Saussure [9], the language "is the social part of the speech ([...] it exists only by the virtue of some kind of contract made between the members of a community", "a grammatical system virtually exists in each brain". The meaning of this "virtual existence" is harder to decode, however, the Saussurian "social" are a restricted meaning, the one of multi-individual.

The Saussurian approach is dominated by the langue-parole opposition, the second term referring not at social level but at the level of the individual speaker. The approach leads to a paradox: any speaker has knowledge about the language structure; thus, the necessary data for studying language can be obtained from the statements made by any person, including of the linguistic inquirer. On the other hand, by only examining the individual linguistic behavior, we can gather data about the language. What was called the "Saussurian paradox" can be stated as follows: the social aspect of the language is studied by observing the individual and its individual aspect by integrating the individual in the community. The American pragmatic-operationalism school, firstly in a polemic spirit to the behaviorism of BurrhusSkinner [17], then by a normative and even dogmatic manner (here, the word is pejorative), sets out the competence at the level of the abstract knowledge of language rules and the performance at the level of the selection and combination of the respective rules. Underlining the competence / performance dichotomy, Noam Chomsky refers to linguistic competence and offers a practical application to the Saussurian paradox: the object itself of the linguistic study is an abstract, homogenous linguistic community in which everybody speaks the same thing and learns the language immediately, at a given moment.

The behavioral linguists transcribe the virtual by the syntagm "directed to any practical purpose". However, 
Saussurian exegetes such as Andre Martinet requested that the linguistic explanation to be limited to the interrelations between the internal, structural factors and not to the commitment of on-site investigations or ideas of collective or individual behavior. There is no need to leave in searching our language, you hear it anywhere, you "bathe" in its effluviums - you just need to assume it, you must come in it and then other will come towards you, in its searching. The language is distinguished by talking, on one hand, and by speech or "language as a whole", on the other hand. The language is considered homogenous as the speech is considered heterogeneous (the former has a diachronic aspect, the latter has a synchronic aspect). The former is a continuous reality, the latter is discontinuous. To talking, an element of discursive and communicative performance, as Jurgen Habermas[12] describe it, we will also associate other ways which are more exigent, maybe even solemn, like "saying", "enunciation", "expression", "wording".

By this universal grammar we understand a corpus of rules within the vocabulary and of semiotic structures of the natural speech - which does not fundamentally depend on the language. Around them, $a X$-bar theory is made (with the additional presupposition of accepting a structure of depth of the speech) or a $X$-theory (a case in which we assume only the existence of a surface structure). The " $\mathrm{X}$ " designates the main correctly constructed syntagms, nominal and verbal, to which the logical phrases are added, seen as a correct connection of these syntagms. The deep structure designates a collection of mental and linguistic algorithms used in the action of speaking or writing and the surface structure collates, as much as possible, the linguistic algorithms.[4]

Regarding the relations between thinking and language, a psycho-linguist interested by the stages of intelligence development, Robert E. Owen[14], offers four types of models. The study of this relation since very young ages, the stages of the perception of notions in various steps of childhood - all these are an entry key to the psychology of development which brings up alternative models 1)-4): 1) Speech and thinking are independent but have abilities correlated between them, which are mutually transmitted (as the Chomskyan School of generative grammars supports but on close position we may also mention Jean Piaget, PiotrGalperin, Tatiana Slama - Cazacu); 2) the cognitive processes precede the speech but later on they are influenced by the speech (the experiments of Lev S. Vagotski); 3) the qualities of thinking are determined by speech (the linguistic determinism supported by Benjamin Whorf and Edward Sapir); 4) the speech is not only based on thinking but it is also determined by it (cognitive determinism embraced by Jerome Bruner and by the cognitivist models of speech).

On the other hand, there are differences of semiosis (the general activity of processing of signs) regarding children and adults. Between the development of human thinking and the logical-linguistic communication abilities there is close connection. The Transformist School of Jean Piaget highlights five stages of the development of intelligence and representation abilities until the age of 17-18 years (the first one being the sensorial-motor intelligence and the last one being the operatorial-formal intelligence), after which the individual is considered mature from a mental point of view: the intelligence tests are the same for the 18 year old and for the 60 year old (for example) but the pathological cases of intelligence decrease drives them to small mental ages.

In a "cordial tension" with the Transformist School of Jean Piaget there was the Nativist School of Noam Chomsky which asserts the existence of a universal grammar at brain level as early as a young age - an interiorized and acquired aspect of the speech. For transformists, this universal grammar is decisively formed until reaching adulthood; for innatists, it is an acquired structure.

In the first life years, the natural speech is developed in a close relation with intelligence, broadly configuring the features of thinking. The child's mind has a small number of reference system from which he/she can make, by experience, his/her qualities which are the basis of processing the knowledge and abilities formed at the level of representation. When adulthood is reached, together with the development of thinking, the mind builds procedures of significance and communication that surpass the natural speech.

The activity of the Chomskyan School after 1980 is focused on the government-binding grammar, at the same time with the activity of school proposing concurrent models (firstly, the Dutch functional-lexical grammar or the British grammar of hyper-structures of constituents). The prescriptions of a general syntax, closely related to the semantics elaborated around a set of primitives are essential in specifying the $G U$-rules. Confronted with the semantic difficulties generated by transformational grammars, Noam Chomsky elaborated in the 1980s a broader analytical system, the government-binding grammar $(G B)$. Another essential idea of $G B$ is the replacement of the binary tree structure for the sentence, $S \rightarrow N V$, used by the transformational grammar, with a ternary tree structure, $S \rightarrow N$ Infl $V$, "infl" being the operation of inflection - of linking a subject to a predicate, then " $\mathrm{S}$ " = "sentence" (sentence, enunciation), $\mathrm{N}$ $=$ "name", $\mathrm{V}=$ "verb".

The X-bar theory is an essential component of the Government-Binding Grammar. The prescriptions of this theory refer to the syntactic groups (that do not form yet mandatorily sentences) and, by extension, to sentences sufficiently simplified and to propositional clauses. The elaborated phrases are analyzed, in the current grammars of computational linguistics (especially in Government and Binding Grammar of Noam Chomsky [4]and Lexical Functional Grammar), by subordinated theories and special principles. The X-bar theory can be applied not only to the languages having a general structure of the $S V O$ sentence (English, Romanian) but also to other structures such as $\mathrm{SOV}$ [2]. Of course, $\mathrm{S}=$,,subject” and $\mathrm{O}=$,object”. Associated to the vocabulary - text - speech triad, the theory of lexical description, the X-bar theory (applied to the text syntax) and declarative pragmatics allow the systematization of literary 
and scientific texts. Highlighted in the vocabulary and in the text, the fundamental (notion and sentence) and derived logical categories allow the construction of four types of systems with axioms and rules, a construction that can be capitalized in a knowledge basis.

We may take into account, for applying the X-bar theory in the case of Romanian language, the following structure:
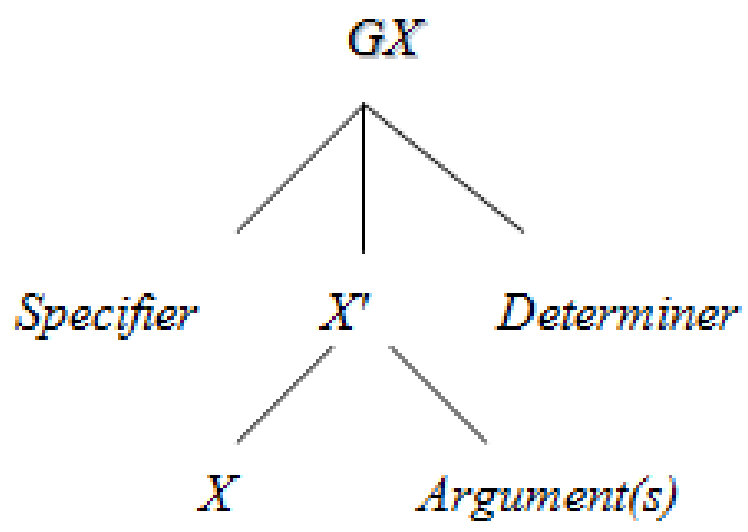

Adapted by Romanian researchers Nicolae Curteanu, Oana Poparda and Ioan Oprea for Romanian language [5] with the term Modifier instead of Determiner. Moreover, the Romanian researchers admit the presence of several arguments of $\mathrm{X}$ - not only one. In the same paperwork, we also tried to invert the Specifier and the Determiner to make room for the definition by proximal gender (Determiner) and specific difference (Specifier). There are also serious performances on the structure of the nominal and verbal group in the Romanian language [10], although the Romanian researchers seem to be around the subject, in a beautiful relationship of incoordination!

In our opinion, the logical structuring of the predicate (verbal or nominal) with the help of arguments is satisfactory to the analytical requirements, a thing which is not happening with the "logical structure of the subject"a much more polysemic notion. For example, according to the Brentanian interpretation, having the verbal center of "to be", the enunciation "all people are mortals" becomes $\forall x$ (human $(x) \Rightarrow$ mortal $(x))$, where human and mortal are predicates of a single variable, since the verb has, in this case, a copulative meaning, coupling an undetermined propriety with a second, determined one. However, if the construction would have the notion of "human" in the center (in order to talk about all people), we hit an annoying linearity of the noun, which also admits collocations with another noun (for example, "stone man" or "with a heart of stone") and with the adjective ("good man") and with the verb ("human running or being in motion") and with the morphological categories that substitute, in the end, classes of nouns such as the pronoun ("this human") and the numeral ("number one human").

We may adhere to any of the four models of the speechthinking relationship, without inventing linguistic, psychological or neurological arguments; since we can "check", to each model" at least one reliable empirical argument. The 4) model configures the prerequisites of the mono- or multi-linguistic cognitive creativity: Jerome $S$. Bruner considered that generally at a fragile mental age, the child can assimilate any didactic content such as learning the Sanskrit language in the $1^{\text {st }}$ grade. In 1970, the psychologist stated: "any child can be taught at any age level any educational object" - obviously, in determined conditions, as MileuZlate [19] observed. The current cognitivism relies on the comparison of the immature brain with a vacuum expert-system on the computer: both the brain and the operation system are equipped with many inferential rules and the "lexical charge", i.e. a certain linguistic content, can be delivered later on without affecting the "inferential machine"! This "machine" means, in fact, the "way of thinking" of a person.

\section{The Languages of Human, Animal or Artificial Intelligence}

It is known that the center of the language is located in the left hemisphere for right-hand people, which imprints in the linguistic theory a primate of competence on the performance (the written language contributes more to linguistic education than the oral one). In disadvantaged populations, where the parents neglect writing for two consecutive generations (based on the premise that the oral language is enough for the child to make something of himself in life!), dysgraphia phenomena occur more often: the student learns the handwritten letters but has difficulties in writing words. For left-handed people, the hemisphere is reversed; it was found out that the insistence to determine the student to write with his right hand triggers major psychic disturbances to certain subjects since, usually, the "emotional" and the "cognitive" are localized on different brain hemispheres. In the dispute between "localizationism" and "antilocalizationism", the first movement won, in the way that the areas for customized actions such as reading, writing, laughter, crying are represented on the right or left brain hemispheres with a pretty high precision.

The language is a communication phenomenon developed in a given social-historical niche, a social generalized fact for a community - through it, we may overlap it on the social fact of Emile Durkheim or, due to its systemic character, on the total social fact proposed by Marcel Mauss as a basis, support of the communion, a first step towards the social. Far from being fiction, the language is a reality, although abstract which is found in the mind of all individual belonging to a community. Since the start of the last century, the Swiss Ferdinand de Saussure placed the competence at language level - considered by him as being a social part of speech - and the performance at the level of speaking. We will consider the language as the natural language located in a given socio-historical community.

The language of a community represents a development 
environment for the individual due to the close relation between thinking and speaking. When someone speaks ill on the street, this should not bother us: it is his speaking, not ours. But already his speaking has an ethical and behavioral connotation. We, the language keepers, are sensing its formative role not only in the oral speech but also in the action related and noetic speech. Being a large house in which we all live, the language hardly supports uncleanliness; it is like our neighbor would throw his garbage on the street. Therefore, the language predetermines us, as a master, we are simply its apprentices.

Language and speaking covers the areas of linguistic performance and competence - and the division represents the basis of some broader types of competence (to learn means to acquire a language!). For instance, if we possess a vocabulary to the noetic language and some (meta) rules of its creation, we may talk about mental competence and performance. Competence consists in the ability of the ideal speaker to manage an abstract system of generative (related to speaking) rules. In the lexemic corpus, over which many rules of various types are made, an infinite set of correct formulations is generated over a certain language.

The brain physiology, directed towards performance, allows the work with few concomitant notions (the so-called " $5+2$ " law) and with linguistic trees with fairly few levels on the vertical - trees that would enter, as algorithmic components", in the nominal / verbal / adjectival / prepositional group. Therefore, a small part of rules and mechanisms will be currently used. Performance defines the application of the competence level at an effective communication situation. The position of the instrumentalist-pragmatic school is without a doubt: the coach is a competent man, the athlete is a high performance one. Each of them can be competent and high performance but with extremely high difficulty; the coach was once high performance, the athlete has the chance to become competent in a certain field.

In the process of enunciation, the occurrence of the code tends to disturb the already churned waters of the meaning from a logical-linguistic point of view, on one hand, and hermeneutic point of view, on the other hand. The logician or the linguist tends to attribute to any sequence of "semiotic material" the acceptation of code, whilst the hermeneutician, sinking in meanings that are often obscure, may reject the idea of "logical form", diving in a speech without substratum. The codes can be understood as functions of some social relationships - but, in this way, we favor the point of view of sociolinguistics. Thus, we keep ourselves within the limits of the coding operation - as explicit formulation of the rules with a code (with orthography and orthoepy, lexicology, morphology etc.).

In any case, the relationship between code and language is harder to clarify. John Humpertz associates the code, a term of the communication theory, with a language, compared to the sub-code represented by dialect, jargon, slang. For Basil Bernstein, the code is a variable in relation with the verbal habits of a population [11]. The elaborated codes prepare and offer a relatively well explained meaning, representing a transmission mean of some individual verbal responses; it shows the possibility to change social roles, comprising two registries: relations between persons and relations between objects. They have no predictive function, they are hard to predict compared to the restricted ones that are completely predictable for the speaker or listener, "condensing", for example, a ritualic behavior. We remark that a general function of the code would be the definition and consolidation of a social relationship form such as integration. Several layers of codes: mimetic, diegetic, analogical and digital.

The German psychologist Karl Buhler distinguishes three functions of the language which correspond to the three essential factors of the communication process: issuer, receiver, message [16], and namely the emotive, conative, respectively representative (or descriptive) functions. Karl R. Popper adheres to the model of Karl and Karlotta Buhler and, taking their steps, considers that the signaling and expressive functions correspond to the animal language, whilst the representative function can be split in other two functions: descriptive and argumentative, the last two attributing them only to the human being [15].

In linguistics, Roman Jakobson starts from the mathematic theory of information and confers to the Saussurian langue-parole couple a new operational value. Jakobson saw in this theory a way of reconcile the linguistics of forms with the one of functions. In his vision, the speakers belonging to the same linguistic community can be defined as effective users of the same code, comprising the same legisigns. A common code is a communication instruments allowing the exchange of message and which it effectively constitutes. In this perspective, the language is a code providing the reversibility of message independent from the source, recipient and coding system. Communication is the transmission of information with the help of a language code independent from the speaker and the semiosis (situational analysis of message transmission) engages six poles: issuer, receiver (connected via a message and using a communication channel) and the denotation of a referent or a context via a code is often made!

Tatiana Slama-Cazacu proposes as a reply a "dynamic-contextualist" model of communication, taking into account the fact that the semiotic diagram of Jakobson does not make a distinction between referent (real object) and the context (the "background" on which the object is designed). The communication model proposed by Slama-Cazacu distinguishes from the classical one of Claude Shannon by the elements of communication: issuer, receiver, channel and context. The context becomes a basic component and highlights the reversibility of the relationship between the receiver and issuer. The presented contextual levels are: explicit context (the linguistic and extralinguistic one), implicit context (individual linguistic system of the issuer) and the social-historical context (the issuer-receiver 
relationship, the special social community, the society in general). These contextual levels act simultaneously on each message unit.

The existence of the language principles leads to a world's portrayal that became coherent due to the principles of physics and social tradition. MihailBahtin wrote in 1977: "the words operate as an essential element accompanying any ideological creation of any kind" [1]. According to the linguistic determinism of Wilhelm von Humboldt and to his successor Ernst von Cassirer, "what distinguishes the languages has no connection with the sounds and signs but consists in the visions about the world". Presenting the language as a medium of the human being, Hans-Georg Gadamer stated three fundamental proprieties of it: self-abandonment, absence of an individual ego and universality of language [13].

Summoning various cultural resources, we may draw the conclusion that the language contains our image on the world: based on this aspect, the symbolic imagination is more powerful than the iconic one (based on signs and symptoms of the visual). From the first mumbling to the wording of the first concepts, the child's thinking and language go hand in hand. In the last instance, the school develops not only the behavior but only the procurement of knowledge of the trained subject: from about one hundred notions in the $1^{\text {st }}$ grade to over 1200 in the last high school grade - if we would consider that, from one year to another, the student acquires hundreds of new notions or concepts.

However, the relationship between thinking and language starts only now: together with the highlighting of the human being as pretty sophisticated knowing agent by his comparison with animals and plants but less able when we compare him not to other being on Earth but with the beings of the sky: with extraterrestrial beings or with angels. And the human being discloses its resources in the cogito inference of Rene Descartes.

From this point, the work within the logic of the notion or statement is not enough and we must pass to more permissible thinking systems. To proper notions ("ordinary"), with proximal gender and specific difference, we will add difficult notions and namely concepts and categories. We will agree on the fact that regarding the concepts we have difficulties related to highlighting either the proximal gender or the specific difference and the categories will be broadest concepts. The "body" and the "psyche" are concepts, not ordinary notions; even "thinking" or "language" operates in a conceptual manner under the "threat" of polysemy.

\section{Cartesian Dualism Face to Face with the Prescriptions of the Scientific Method}

René Descartes (1596 - 1650) developed a dualist concept regarding the body / psyche issue, mentioning at least two alternatives of dualism. In Meditationes de prima philosophia. Réponses secondes objections, published in 1641, the rationalist philosopher supports the thesis of a separationist dualism: "Anything that may think is Spirit. However, since the Spirit and the Body are virtually Spirit, a body is not a Spirit. Consequently, a body cannot think". From the impossibility of propriety transfer from spirit to body, it results that the latter cannot think. The soul is without extension and immaterial; in current terms, remaining with the informational space but, although we are currently aware of transformation fields between information types, we have available examples of information disconnected from the substrate and "supported" only by the existence of a field.

The second version of dualism - the interactionist one - is supported in the $4^{\text {th }}$ (Proof of God and the Soul or the bases of metaphysics) and in the $5^{\text {th }}$ (Order of problems in physics) of the Discourse on the method (1637): "After that we described the rational soul and we showed that it cannot come in any way from the power of the matter as other things we talked about; necessarily, it must be created and it is not enough to be put in the human body as a helmsman on his ship, in order move only its limbs but it is necessary for the body to be closely related to the body in order not to have, besides this connection, feelings and desires similar to ours, thus forming a true man." [6] Here we have a comparison influenced by Aristotle: the psyche is a sailor put on his ship, the body - as it cannot be conceived otherwise. Death is associated with the psyche leaving the body, the latter becoming cold and still and the former wandering through our world or capitalizing its ascending proprieties.

At the end of the same paragraph, the immortality of the soul is stated based on two assumptions: i) the difference between the human and the animal soul through the Creation phenomenon; ii) the distinct nature of the soul in comparison with the body, which conceptually separates the death of the two. The heterogeneity of the body / psyche complex - the first one being reduced in the animal regnum to a simple machine - intrigues the first commentators: how can the psyche (without extension, immaterial) put the body in motion? And why the ability to move of the body is not associated with an immaterial entity?

Discourse on the method is in fact a preface of Descartes for three scientific treatises: the first one about dioptrics (optics), the second is related to meteorology and the last one to geometry[6].

Some may raise the objection that we use scientific terms for designating an issue (body and psyche) and that we do not report to the usual terms, body and soul. However, the scientific terms are more adequate for a current approach. Referring to the dualist movement in the history of religions, Ugo Bianchi stated that religions and life conceptions are dualist according to which two principles, co-eternal or not, found the existence, real or apparent, of what is manifested in the world. Christianity is not dualist concerning ethics since the principle of Good is universal, as long as the evil is particular, coming from the diversity of the world created by 
God (if we refer to the explanation given by Leibniz in Monadology). However, there are variants of gnoses and heresies in which a universal evil tends to "balance" the divine good.

The philosophy of the mind is the study of the body / psyche problem (and of the consequences of its solving), not of the body / soul problem. If we "quadruplicate" the terms, this would an error of argumentation. However, for the time being, we will make a table containing the features of the body and soul - as they are offered to rationalists by a millenary tradition:

Table 1. The features of the body compared to the features of the soul in the conception of Antiquity and Medieval thinkers

\begin{tabular}{|c|c|c|}
\hline Current no. of attribute & Body & Soul \\
\hline 1. & Composed & Simple (indivisible) \\
\hline 2. & Corruptible & Incorruptible \\
\hline 3. & Hard & Easy (plasmatic) \\
\hline 4. & Mortal & Immortal \\
\hline 5. & Extended & Non-extended \\
\hline
\end{tabular}

The guarantee of the correct perception of forms is God, not the human free-thinking subject: "it is shown in what way it is true that the safety of geometrical demonstrations, however, hands by God's knowledge" [7]We are in full scientific-theological imaginary of the $17^{\text {th }}$ century in which both theist or atheist intellectuals of the time, as well as the God believing ones tried to express the extraordinary proprieties of the soul without a direct reference to a divine presence, but instead based on a theoretical or empirical argumentation, attributing to the human mind certain dignities to which the body cannot aspire - in the virtue of some strong cultural traditions.

There are specialists who consider as abusive the "labeling" of Descartes as a dualist, invoking even his assertive statements that he did not intent to "duplicate" the knowing of the human organism but to present a unique human being. However, even the statement of the great thinker are explanatory and himself could have been wrong in assessing his own doctrine: if the spirit is more known than the body ( $3^{\text {rd }}$ meditation) and if there is a (true) distinction between the spirit and the body, as the $6^{\text {th }}$ meditation states, we can hardly go back to a "body / psyche monolith"!

Our body is clearly and distinctly perceived compared to other bodies and its perception indicates to us a direction of exploring the world from inside to outside: my body, the bodies of others, and then the inorganic bodies of the external environment. Rene Descartes agrees with this empirical argument for the support of clear existences (my body), however, he is aware that empirical arguments can send us to grope in the dark. For the almost permanentized doubt of "trial and error" algorithms to be fruitful, we must be convinced that there is at least a solution; otherwise the doubt is groping in the dark. Thus, Descartes decided to bring the human spirit "to the light of the truth".

\section{Conclusions}

Thinking is the superior cognitive process of extracting the essential, logical and necessary features with the help of some abstract-formal operations for understanding, explaining and predicting some causal relations of reality and creating some concepts, notions, theories, cognitive systems as mental models of reality. Cognitive processing has a deep character, has a high degree of mental autonomy, a maximum level of selectivity in relation with the features of the world and life. Categorization represents the process of grouping on classes of the information avalanche we enter into contact every day. This information is grouped on classes, categories after certain criteria.

Defying the diversity of the representation systems, the science of cognition accedes to paradigms in which the traditional axes of the communication theory (issuer receptor, signifier - signified, denotation - connotation) also operate within typologies other than the ones of the sign implanted in the social, authoritarian and stable. But the epistemic aspects of representation do not cease to occur: from the raw representation with a mnesic function of the psychologist, passing through generic field representations, expressed by notions and statements, also evoking social representations (rumors, clichés, signs of power), we reach the representations from the knowledge bases by which we surpass the operations on notions and statements, driving towards transfrastic forms of the reasoning. To a great extent, these representations also have an imagistic basis.

In conclusion it is simpler to set out a connection between the vocabulary (in order to also have access to language and, in a broader sense, to the machine's language), text and discourse. The vocabulary is an inventory (open) of semiotic availabilities for a knowing agent which, can be human, animal, vegetal or even of physical provenience (the wind, for example). The text is a logical-grammatical sequence correctly constructed within a vocabulary with a unitary significance and the discourse is the text together with the entire show of social presentation. Within the vocabulary, the explanation operation takes place, encryption and encoding take place in the text and in the discourse.

\section{REFERENCES}

[1] Bakhtine, M., Le marxisme et la philosophie du language, Les Éditions de Minuit, Paris, 1977

[2] Black, Cheryl A., A step-by-step introduction to the Government and Binding theory of syntax, http://www.sil.org/americas/mexico/ling/E2002-introGB.pdf [February 1999]

[3] Chomsky, N., Current Issues in Linguistic Theory, The Mouton, Hague, 1964

[4] Chomsky, N., Lectures on Government and Binding, Foris, Dordrecht, 1981 
[5] Curteanu, N., Popârda, O., Oprea, I., An Algorithmic Description of the Syntactic Behavior of Noun Groups, "Computers and Artificial Intelligence", an VI, 1 / 1988, pp. 17-34; Nicolae Curteanu, Oana Popârda, X'-schemas de représentation des modificateurs de nature verbale, "Revue roumaine de linguistique“", XXXIII, 1, 1988

[6] Descartes, R., Discours de la méthode, plus la dioptrique, les météores et la géométrie, Éditions „Fayard“, Paris, 1987

[7] Descartes, R., Două tratate filosofice. Viaţa şi filosofia lui René Descartesde Constantin Noica, Editura Humanitas, Bucureşti, 1992

[8] Descartes, R.,Discurs despre metoda de a ne conduce bine raţiunea şi a căuta adevărul în ştiinţe, în: Alexandru Boboc (ed.), Descartes şi spiritul ştiinţific modern, traducere din franceză de Daniela Rovenţa-Frumuşani, Editura Academiei Române, Bucureşti, 1990

[9] Ferdinand de Saussure, Cours de linguistique générale, Edition Payot, Paris, 1975

[10] Florea, M., Structuragrupului nominal inlimbaromânăcntemporană,

EdituraŞtiinţificăşiEnciclopedică, Bucureşti, 1983, pp. 28-99; Gabriela PanăDindelegan, Sintaxatransformaţională a grupului verbal înlimbaromână, EdituraAcademiei, Bucureşti, 1974
[11] Ionescu-Ruxăndroiu, L., Chițoran, D., Sociolingvistică, Editura Didactică şi Pedagogică, Bucureşti, 1975

[12] Jurgen Habermas, Cunoaştere şi comunicare, Editura Politică, Bucureşti, 1983

[13] Munteanu, E., Hans-Georg Gadamer: limba ca medium al fiinţei umane, „Signa in rebus. Studia semiologica et lingvistica in honorem M. Carpov"“, Supliment la „Anale ştiinţifice ale Universităţii «Al. I. Cuza»", Secţia Lingvistică şi limbi străine, 2005

[14] Owens, R. E. Jr., Language development. An Introduction, Second Edition, Macmillan Publ. Comp., New York, 1988

[15] Popper, Karl R. în: Angela Botez (ed.), Filosofia mentalului, Editura Ştiinţifică, Bucureşti, 1996

[16] Sebeok, T., Jocul cu fantasme. Semiotică şi antropologie, traducere de Mariana Neţ, Editura All, Bucureşti, 2002

[17] Solomon Marcus, A învăţa înseamnă a deprinde un limbaj, în: Solomon Marcus (coord.), Modele matematice şi semiotice ale dezvoltării sociale, Editura Academiei, Bucureşti, 1986

[18] Wittgenstein, L., Tractatus logico-philosophicus, Editura Humanitas, Bucureşti, 1994

[19] Zlate, M., Fundamentele psihologiei, Editura Universitară, Bucureşti, 2006 